\title{
PRODUKSI DAN KOMPOSISI SUSU KAMBING PERANAKAN ETTAWA DI DATARAN TINGGI DAN DATARAN RENDAH DAERAH ISTIMEWA YOGYAKARTA
}

\section{MILK PRODUCTION AND MILK COMPOSITION OF ETTAWA GRADE GOATS IN HIGHLAND AND LOWLAND AREA OF YOGYAKARTA}

\author{
Rian Rosartio ${ }^{1 *}$, Yuni Suranindyah ${ }^{2}$, Sigit Bintara ${ }^{2}$, dan Ismaya ${ }^{2}$ \\ ${ }^{1}$ Loka Penelitian Kambing Potong, Sumatera Utara, 20585 \\ ${ }^{2}$ Fakultas Peternakan, Universitas Gadjah Mada, Yogyakarta, 55281
}

Submitted: 10 November 2014, Accepted: 25 August 2015

\section{INTISAR}

Penelitian ini bertujuan untuk mengetahui dan membandingkan produksi dan komposisi susu kambing daerah dataran tinggi dan dataran rendah di Daerah Istimewa Yogyakarta. Kambing yang digunakan dalam penelitian adalah 10 induk laktasi kambing Peranakan Ettawa di masing-masing lokasi yaitu Kabupaten Kulon Progo dan Bantul. Data yang diambil terdiri dari kondisi lingkungan, konsumsi pakan, produksi dan komposisi susu yang terdiri dari kadar lemak, kadar protein, dan berat jenis. Pengukuran dilakukan dalam 3 ulangan, dengan tiap ulangan selama 7 hari, pada awal, pertengahan dan akhir periode. Konsumsi pakan diukur selama 21 hari. Produksi susu diukur dari hasil pemerahan pagi dan sore. Data yang diperoleh dianalisis statistik menggunakan analisis One way-Anova. Konsumsi nutrisi kambing di Kabupaten Kulon Progo lebih besar daripada Bantul $(P<0,05)$. Rerata konsumsi bahan kering, protein kasar, serat kasar, dan total digestible nutrient kambing di Kulon Progo berturut-turut adalah $95,98 \mathrm{~g} ; 14,26 \mathrm{~g} ; 14,26 \mathrm{~g}$, dan 0,06 kg/kg BB ${ }^{0,75}$ sedangkan di Bantul $86,96 \mathrm{~g} ; 10,87 \mathrm{~g} ; 19,23 \mathrm{~g}$, dan $0,05 / \mathrm{kg} \mathrm{BB}^{0,75}$. Rerata produksi susu, kadar lemak, kadar protein, dan total bahan padat susu kambing di Kulon Progo adalah 501,71 g/hari; 4,84\%, 4,41\%, dan 13,26\% sedangkan di Bantul 419,62 197,08 g/hari; $6,30 \% ; 3,97 \%$, dan $14,69 \%$. Kesimpulan dari penelitian ini adalah kondisi lingkungan menyebabkan perbedaan produksi dan komposisi susu kambing Peranakan Ettawa salah satunya diakibatkan oleh perbedaan komposisi pakan dan konsumsi nutrien, sebagaimana hasil yang diperoleh di Kulon Progo dan Bantul.

(Kata kunci: Dataran rendah, Dataran tinggi, Kambing Peranakan Ettawa, Komposisi susu, Produksi)

\section{ABSTRACT}

The objective of this study was to determine the differences of milk production and compotition of Ettawa Crossbred goats in highland and lowland area of Yogyakarta. The study used ten lactating Ettawa Crossbred goats in each area. The areas were Kulon Progo and Bantul Regency. Data environmental condition, feed intake, milk production and milk composition which consisted of milk gravity, fat and protein content were measured three times, those were in the beginning, middle and the end of the study period. Feed intake was measured everyday for 21 consecutive days. Milk production was measured by milking goat every morning and evening. Data was analyzed using One Way-Anova. Nutrient consumption of goat in Kulon Progo was higher than that in Bantul $(P<0.05)$. Mean consumption of dry matter, crude protein, crude fiber and total digestible nutrient of goat in Kulon Progo were $95.98 \mathrm{~g}$; $14.26 \mathrm{~g} ; 14.26 \mathrm{~g}$ and $0.06 \mathrm{~kg} / \mathrm{kg}$ BW ${ }^{0.75}$ respectively, while those in Bantul were $86.96 \mathrm{~g} ; 10.87 \mathrm{~g} ; 19.23 \mathrm{~g}$ and $0.05 / \mathrm{kg} \mathrm{BW.75}$. The average production, fat, milk and total solid of goat milk in Kulon Progo were $501.71 \mathrm{~g} /$ day; $4.84 \%, 4.41 \%$ and $13.26 \%$ while in Bantul were $419.62 \mathrm{~g} /$ day, $6.30 \%$; 3.97\% and $14.69 \%$ respectively. It was concluded that different areas of highland and lowland resulted differences on milk production and milk compotition of Etawah Crossbred goats due to differerences in feed composition and nutrien consumption.

(Key words: Ettawa Crossbred goats, Highland, Lowland, Milk compotition, Milk production)

\footnotetext{
* Korespondensi (corresponding author):

Telp. +62 81326862314

E-mail: rianrosartio@yahoo.co.id
} 


\section{Pendahuluan}

Pertumbuhan populasi kambing Peranakan Ettawa (PE) sebagai penghasil susu di Daerah Istimewa Yogyakarta semakin meningkat. Keadaan ini disebabkan oleh pemenuhan kebutuhan susu yang berasal dari sapi perah masih kurang, dan karena masyarakat mulai mengenal susu kambing sebagai sumber nutrien yang baik. Kondisi ini menyebabkan meningkatnya minat masyarakat untuk beternak kambing perah. Kambing yang dipilih adalah kambing Peranakan Ettawa, karena merupakan ternak dwiguna, yaitu menghasilkan susu dan daging, sehingga dapat meningkatkan nilai ekonomi pemeliharaan kambing. Alasan lain yang mendasari pemilihan kambing PE untuk dikembangkan adalah sifat pertumbuhannya yang cepat dan litter size mencapai 2 ekor. Pemeliharaan kambing tersebut juga mudah dan tidak membutuhkan lahan yang luas serta produksi dan kandungan gizi susu. Atabany (2002) menyatakan bahwa kualitas susu kambing dipengaruhi oleh beberapa faktor di antaranya adalah pakan, bangsa kambing, dan ketinggian tempat pemeliharaan.

Ketinggian tempat berpengaruh terhadap temperatur lingkungan, produksi dan ketersediaan pakan hijauan, sehingga akan berpengaruh secara tidak langsung terhadap konsumsi pakan, produksi dan kualitas susu yang dihasilkan. Ketinggian tempat juga berpengaruh terhadap temperatur dan adaptasi dengan lingkungan sekitar.

Perkembangan kambing yang pesat menyebabkan lokasi yang dipilih tidak memperhitungkan ketinggian yang ideal. Keadaan ini dapat menyebabkan kambing perah tidak mencapai kemampuan maupun produksi susu yang maksimum. Beberapa peternak memilih memelihara di dataran tinggi, tetapi ada pula yang memilih memelihara kambing perah di daerah dataran rendah. Pemilihan lokasi di dataran rendah karena keadaan ekonomi masyarakat yang tidak dapat membuka lahan untuk lokasi peternakan kambing dan dengan tujuan mendekatkan usaha kambing perah dengan pasar. Oleh karena itu diperlukan studi untuk mengetahui pengaruh perbedaan kondisi lingkungan di dataran tinggi dan dataran rendah terhadap produksi dan kualitas susu kambing di Daerah Istimewa Yogyakarta. Hasil penelitian ini diharapkan dapat digunakan sebagai acuan untuk menentukan apakah dataran rendah cocok sebagai lokasi pemeliharaan kambing PE.

\section{Materi dan Metode}

Penelitian dilakukan
pengamatan langsung pada bulan
September sampai November 2012 di
kelompok peternak kambing PE di desa
Gerbosari, Samigaluh, Kulon Progo dengan
ketinggian 1.000 mdpl, dan di desa
Sumbermulyo, Bambanglipuro, Bantul
dengan ketinggian 100 mdpl dan di
Laboratorium Ilmu Ternak Perah dan Industri
Persusuan Fakultas Peternakan Universitas
Gadjah Mada.

Materi

Sampel yang digunakan dalam penelitian ini adalah 20 ekor induk laktasi kambing yang terdiri dari 10 ekor di dataran tinggi, yaitu peternakan Menoreh Makmur di desa Gerbosari, Samigaluh, Kulon Progo dan 10 ekor kambing di dataran rendah yaitu peternakan di desa Sumbermulyo, Bambanglipuro, Bantul. Kambing yang digunakan di masing-masing lokasi adalah kambing dengan laktasi ketiga. Alat yang digunakan pada pengukuran produksi susu dan konsumsi pakan kambing PE adalah ember, gelas ukur dan timbangan. Alat dan bahan yang digunakan dalam uji komposisi susu adalah kemikalia dan peralatan uji protein menurut metode Kjehdal, uji kadar lemak menurut metode Babcock dan laktodensimeter untuk mengukur berat jenis.

\section{Metode}

Pengukuran data lingkungan. Pengukuran data lingkungan dilakukan dengan pencatatan temperatur dan kelembaban dari temperatur lingkungan yang ditempel di kandang. Pencatatan dilakukan selama 21 hari setiap pagi (07.00 WIB), siang (12.00 WIB), dan malam hari (18.00 WIB). Pencatatan temperatur dilakukan pada musim kemarau.

Pencatatan data ternak. Kambing dicatat mulai dari umur, masa laktasi, berat badan dan juga ukuran tubuh meliputi panjang badan, lingkar dada, dan tinggi badan. Umur ditentukan dengan melihat susunan gigi pada sampel kambing.

Pengukuran konsumsi pakan. Konsumsi pakan/ekor/hari diukur dengan menimbang pakan yang diberikan dikurangi 
pakan yang tersisa setelah 24 jam. Pengukuran konsumsi pakan dilakukan dalam 3 periode, dengan 1 periode selama 7 hari, pada awal, pertengahan, dan akhir waktu penelitian. Konsumsi pakan kambing dari setiap lokasi dicatat setiap pagi hari. Pengukuran konsumsi air dilakukan dengan mengukur air minum dan air yang dicampur dengan konsentrat. Pengukuran dilakukan di masing-masing lokasi kelompok peternak di Kecamatan Samigaluh dan Bambanglipuro.

Pengukuran produksi susu. Pengukuran produksi susu dilakukan dengan mencatat besar produksi susu hasil pemerahan pada pagi hari (06.00 WIB) dari 10 ekor induk laktasi per lokasi. Pencatatan produksi susu dilakukan dalam 3 periode, dengan masing-masing periode selama 7 hari.

Pengujian komposisi susu. Metode yang dilakukan dalam uji kualitas susu ini adalah uji kadar protein, kadar lemak, dan berat jenis. Sampel yang diuji adalah susu kambing hasil pemerahan sore. Susu diambil dari 10 kambing masing-masing kelompok peternak di dua lokasi. Susu ditempatkan di botol steril dan dimasukkan ke dalam pendingin sampai keesokan harinya untuk dilakukan pengujian. Penentuan kadar protein menggunakan metode Kjeldahl (AOAC, 1980), penentuan kadar lemak menggunakan metode Babcock (Hadiwiyoto, 1982), dan penentuan berat jenis susu menggunakan laktodensimeter.

\section{Analisis data}

Analisis data yang digunakan dalam penelitian ini menggunakan analisis data One Way-Anova.

\section{Hasil dan Pembahasan}

\section{Topografi lingkungan}

Lokasi penelitian di desa Gerbosari, Kecamatan Samigaluh, Kulon Progo yang merupakan daerah dataran tinggi dan desa Sumbermulyo, Kecamatan Bambanglipuro, Bantul yang merupakan dataran rendah di Daerah Istimewa Yogyakarta. Kedua lokasi tersebut menunjukkan kondisi lingkungan seperti yang terdapat pada Tabel 1 . Pengukuran temperatur dan kelembaban harian dilakukan selama 21 hari pada pagi, siang, dan sore hari dan dilakukan pada musim kemarau.

Desa Gerbosari, Samigaluh, Kulon Progo merupakan dataran tinggi yang berada pada ketinggian 1.000 mdpl memiliki rerata temperatur dan kelembaban harian $26,67 \pm 0,80^{\circ} \mathrm{C}$ dan $69,52 \pm 7,40 \%$. Desa Sumbermulyo, Bambanglipuro, Bantul merupakan daerah dataran rendah dengan ketinggian 100 mdpl yang memiliki rerata temperatur dan kelembaban harian $29,10 \pm 0,70^{\circ} \mathrm{C}$ dan $84,29 \pm 5,07 \%$. Temperatur dan kelembaban lingkungan di Bantul lebih tinggi dibandingkan di Kulon Progo.

Payne (1970) menyatakan bahwa temperatur udara harian rata-rata akan menurun $1,7^{\circ} \mathrm{C}$ untuk setiap peningkatan ketinggian tempat $305 \mathrm{~m}$. Perbedaan ketinggian yaitu $500 \mathrm{~m}$ antara lokasi dataran rendah dan dataran tinggi tersebut menyebabkan perbedaan temperatur dan kelembaban lingkungan yang signifikan. Handoko (1995) menyatakan bahwa semakin jauh dari permukaan laut, semakin berkurang jumlah molekul udara dan semakin rendah tumbukan antara molekul, sehingga temperatur udara semakin rendah.

\section{Data awal sampel kambing}

Kambing yang digunakan dalam penelitian ini merupakan induk laktasi kambing $P E$ dengan data seperti yang tercantum pada Tabel 2 dan 3.

Rerata umur kambing di lokasi Kulon Progo dan Bantul berdasarkan analisis statistik tidak jauh berbeda, yaitu pada kisaran 2 sampai 3 tahun. Pada umur tersebut induk kambing mencapai masa produktif dalam memproduksi susu. Masa laktasi dari kambing PE yang digunakan sebagai sampel di kedua lokasi tersebut menunjukkan perbedaan yang nyata $(P \leq 0,05)$. Meskipun demikian, masa laktasi kambing di kedua lokasi tersebut masih berlangsung pada bulan ke-3. Produksi susu

Tabel 1. Rerata temperatur dan kelembaban lingkungan di lokasi penelitian (the mean of enviromental temperature and humidity in the location)

\begin{tabular}{lcc}
\hline \hline & \multicolumn{2}{c}{ Lokasi (Iocation) } \\
\cline { 2 - 3 } & Kulon Progo & Bantul \\
\hline Temperatur $\left({ }^{\circ} \mathrm{C}\right)\left(\right.$ temperature $\left.\left({ }^{\circ} \mathrm{C}\right)\right)$ & $26,67 \pm 0,80$ & $29,10 \pm 0,70$ \\
Kelembaban $(\%)$ (humidity $(\%))$ & $69,52 \pm 7,40$ & $84,29 \pm 5,07$ \\
\hline
\end{tabular}


Tabel 2. Kondisi awal sampel kambing (goat sample condition at the beginning of the study)

\begin{tabular}{|c|c|c|}
\hline & \multicolumn{2}{|c|}{ "Lokasi (Iocation) } \\
\hline & Kulon Progo & Bantul \\
\hline Umur (tahun) (age (year)) ns & $2,40 \pm 0,70$ & $2,50 \pm 0,53$ \\
\hline Masa laktasi (hari) (lactation period (day)) & $88,50 \pm 21,35^{a}$ & $82,50 \pm 14,39^{b}$ \\
\hline
\end{tabular}

Tabel 3. Rerata ukuran tubuh kambing

(the mean of body size of the goats)

\begin{tabular}{lcc}
\hline \hline & \multicolumn{2}{c}{ Lokasi (location) } \\
\cline { 2 - 3 } & Kulon Progo & Bantul \\
\hline Panjang badan $(\mathrm{cm})(\text { length of body }(\mathrm{cm}))^{\mathrm{ns}}$ & $60,80 \pm 6,65$ & $59,50 \pm 1,58$ \\
Lingkar dada $(\mathrm{cm})($ birth of chest $(\mathrm{cm}))$ & $81,30 \pm 1,42^{\mathrm{a}}$ & $79,40 \pm 2,81^{\mathrm{b}}$ \\
Tinggi gumba $(\mathrm{cm})($ height at the withers $(\mathrm{cm}))$ & $76,00 \pm 3,50^{\mathrm{a}}$ & $74,10 \pm 2,81^{\mathrm{b}}$ \\
Berat badan $(\mathrm{kg})(\text { body weight }(\mathrm{kg}))^{\mathrm{ns}}$ & $39,18 \pm 7,04$ & $38,38 \pm 2,97$ \\
\hline ns $\quad$ berbeda tidak nyata $($ non significant). & & \\
a,b Superskrip yang berbeda pada baris yang sama menunjukkan perbedaan yang nyata $(\mathrm{P} \leq 0,05)$ (different \\
$\quad$ superscripts at the same row indicate significant differences $(P \leq 0.05))$.
\end{tabular}

kambing pada masa laktasi tersebut sudah melewati puncak produksi. Devendra dan Burn (1994) menyatakan bahwa produksi susu kambing dapat dipengaruhi oleh genetik, bangsa, pakan, umur, temperatur lingkungan, dan masa laktasi. Rerata berat badan sampel kambing di Kulon Progo $39,18 \pm 7,04 \mathrm{~kg}$ tidak berbeda nyata dengan Bantul 38,38 $\pm 2,97 \mathrm{~kg}$, sedangkan tinggi gumba dan lingkar dada menunjukkan perbedaan nyata $(P \leq 0,05)$. Ukuran tinggi gumba, panjang badan, dan lingkar dada kambing di Kulon Progo dan Bantul berada dalam kisaran ukuran tubuh kambing PE di peternak. Ganong (1991) menyatakan bahwa kambing bisa mencapai tinggi gumba $65 \mathrm{~cm}$, panjang badan $70 \mathrm{~cm}$, dan berat badan 50 kg.

\section{Pakan kambing}

Pakan yang diberikan pada kambing di kelompok peternak Kulon Progo dan Bantul, berupa konsentrat dan hijauan. Meskipun demikian, jenis konsentrat dan hijauan tersebut berbeda.

Kambing PE yang berada di Kulon Progo diberi hijauan terdiri dari kaliandra, daun singkong, dan daun sengon dengan proporsi $80 \%$, $10 \%$, dan $10 \%$, sedangkan konsentrat yang diberikan adalah pollard dan kulit kedelai (kleci) dengan proporsi $70 \%$ dan $30 \%$. Kambing PE di Bantul diberi hijauan berupa gliricidia dan rumput kolonjono dengan proporsi $50 \%$ dan $50 \%$, sedangkan konsentrat berupa dedak, pollard, dan kleci dengan proporsi $40 \%, 40 \%$, dan $20 \%$.

Berdasarkan proporsi dari jenis hijauan maupun konsentrat yang diberikan pada kambing, dapat diketahui bahwa kandungan nutrien hijauan maupun konsentrat di Kulon Progo lebih tinggi dibandingkan Bantul. Pakan hijauan yang diberikan pada kambing laktasi di Kulon Progo mengandung BK 29,61\%; PK 15,48\%; SK $18,37 \%$ dan energi dalam bentuk total digestible energi (TDN) 60,86\% sedangkan di Bantul pakan hijauan mengandung BK 20,46\%; PK 14,10\%; SK 25,60\% dan TDN $57,50 \%$. Data tersebut menunjukkan bahwa pakan hijauan yang diberikan pada kambing laktasi di Bantul mengandung serat kasar dan kadar air lebih tinggi daripada hijauan di Kulon Progo. Konsentrat yang diberikan pada kambing di Kulon Progo juga mengandung kadar PK dan TDN lebih tinggi sedangkan kadar serat kasarnya lebih rendah. Perbandingan kandungan PK, SK, dan TDN dalam pakan konsentrat di Kulon Progo dan Bantul berturut-turut 13,86 dan $12,23 \% ; \quad 5,46$ dan $10,78 \% ; 72,63$ dan $65,69 \%$.

\section{Konsumsi pakan dan nutrien}

Rerata konsumsi pakan kambing PE di daerah Kulon Progo 5,26 kg/hari dan di Bantul 4,92 kg/hari, masing-masing terdiri dari hijauan 4,86 dan $4,42 \mathrm{~kg} /$ hari dan konsentrat 0,40 dan 0,50 kg/hari (Tabel 5). Berdasarkan analisis statistik konsumsi 
Tabel 4. Kandungan nutrien bahan pakan yang diberikan pada kambing di lokasi penelitian (nutrient content of the feedstuff of goat in the location)

\begin{tabular}{lcccc}
\hline \hline \multirow{2}{*}{\multicolumn{1}{c}{ Bahan pakan (feedstuffs) }} & \multicolumn{4}{c}{$\begin{array}{c}\text { Kandungan nutrient bahan pakan (\%) } \\
\text { (nutrient content of feed ingredients (\%)) }\end{array}$} \\
\cline { 2 - 5 } & BK & PK & SK & TDN \\
\hline Kaliandra (calliandra) & 30,17 & 16,60 & 17,98 & 60,26 \\
Daun singkong (cassava leaves) & 21,13 & 13,89 & 21,10 & 74,39 \\
Daun sengon (albizia leaves) & 33,65 & 8,15 & 18,78 & 52,11 \\
Rumput kolonjono (kolonjono grass) & 18,00 & 9,10 & 33,10 & 46,00 \\
Gliricidia & 22,92 & 19,10 & 18,00 & 69,00 \\
Pollard & 89,50 & 14,79 & 3,88 & 74,00 \\
Kleci & 92,00 & 11,69 & 9,15 & 69,42 \\
Dedak halus (fine bran) & 91,67 & 9,96 & 18,51 & 55,52 \\
\hline BK: bahan kering (dry matter); PK: protein kasar (crude protein); SK: serat kasar (crude fiber); TDN: total digestible \\
nutrient. \\
1 Hartadi et al. (2005).
\end{tabular}

Tabel 5. Konsumsi pakan dan nutrien harian (daily consumption of feed and nutrient)

\begin{tabular}{|c|c|c|}
\hline \multirow{2}{*}{ Komponen pakan yang dikonsumsi (consumption of feed component) } & \multicolumn{2}{|c|}{ Lokasi (location) } \\
\hline & Kulon Progo & Bantul \\
\hline Hijauan segar (kg/hari) (fresh forage (kg/day)) & 4,86 & 4,42 \\
\hline Konsentrat (kg/hari) (concentrate (kg/day)) & 0,40 & 0,50 \\
\hline Total pakan segar (kg/hari) (total fresh feed (kg/day)) & 5,26 & 4,92 \\
\hline Bahan kering hijauan (kg/hari) (forage dry matter ( $\mathrm{kg} /$ day)) & $1,12^{\mathrm{a}}$ & $0,60^{b}$ \\
\hline Bahan kering konsentrat (kg/hari) (concentrate dry matter (kg/day)) & 0,36 & 0,44 \\
\hline Total bahan kering (kg/hari) (total dry matter (kg/day)) & $1,48^{a}$ & $1,04^{\mathrm{b}}$ \\
\hline Konsumsi air (liter/hari) (water consumption (litter/day)) & 0,50 & 0,70 \\
\hline
\end{tabular}

bahan kering hijauan dan bahan kering pakan secara keseluruhan menunjukkan perbedaan nyata $(P \leq 0,05)$.

Berdasarkan berat badan kambing (Tabel 3) dapat diketahui bahwa rerata konsumsi BK/kg berat badan (BB) ${ }^{0,75}$ pada kambing di Kulon Progo adalah 95,98 g sedangkan di Bantul 86,96 g. Hasil penelitian ini menunjukkan bahwa konsumsi BK pakan kambing yang ada di Kulon Progo lebih besar daripada konsumsi BK kambing di Bantul $(P \leq 0,05)$.

Perbedaan konsumsi bahan kering ini dapat disebabkan oleh faktor temperatur yang rendah di Kulon Progo, sehingga kambing akan lebih banyak mengkonsumsi pakan. Leeson (1986) menyatakan bahwa pada temperatur yang lebih rendah kambing akan mengkonsumsi pakan lebih banyak karena sebagian energi pakan akan diubah menjadi panas untuk mengatasi temperatur lingkungan yang lebih rendah. Perbedaan konsumsi BK juga disebabkan oleh perbedaan jenis pakan yang diberikan.
Kambing PE di Kulon Progo diberi pakan hijauan yang terdiri dari kaliandra, daun singkong, dan daun sengon, sedangkan di Bantul kambing diberi hijauan gliricidia dan kolonjono. Kambing merupakan ternak yang bersifat selektif terhadap pakan dan lebih menyukai dedaunan dari tanaman pohon (rambanan), sehingga palatabilitas pakan kambing di Kulon Progo yang mayoritas berupa kaliandra lebih baik dibandingkan jenis pakan di Bantul. Parakkasi (1999) menyatakan bahwa faktor pakan yang mempengaruhi konsumsi BK pada ruminansia antara lain sifat fisik dan komposisi kimia pakan.

Konsumsi BK/kg BB ${ }^{0,75}$ di kedua lokasi adalah $95,98 \mathrm{~g}$ dan $86,96 \mathrm{~g}$ ekuivalen dengan 3,83\% dan 2,73\% dari $\mathrm{BB}$, masih dalam kisaran konsumsi BK normal pada kambing. Atabany (2002) menyatakan bahwa kambing perah subtropik yang hidup di daerah tropis mempunyai kisaran konsumsi berat kering $2,8 \%$ sampai $4,9 \%$ dari BB. 
Tabel 6. Rerata konsumsi nutrien

(the mean of nutrient consumption)

\begin{tabular}{|c|c|c|}
\hline \multirow[b]{2}{*}{ Jenis nutrien terkonsumsi (type of nutrient consumption) } & \multicolumn{2}{|c|}{ Lokasi (location) } \\
\hline & Kulon Progo & Bantul \\
\hline Protein kasar hijauan (g/hari) (forage crude protein (g/day)) & $170^{\mathrm{a}}$ & $70^{\mathrm{b}}$ \\
\hline Protein kasar konsentrat (g/hari) (concentrate crude protein (g/day)) & $50^{a}$ & $60^{\mathrm{b}}$ \\
\hline Total protein kasar (g/hari) (total crude protein (g/day)) & $220^{a}$ & $130^{\mathrm{b}}$ \\
\hline Serat kasar hijauan (g/hari) (forage crude fiber (g/day)) & $200^{\mathrm{a}}$ & $180^{\mathrm{b}}$ \\
\hline Serat kasar konsentrat (g/hari) (concentrate crude fiber (g/day)) & $20^{\mathrm{a}}$ & $50^{\mathrm{b}}$ \\
\hline Total serat kasar (g/hari) (total crude fiber (g/day)) & $220^{\mathrm{a}}$ & $230^{\mathrm{b}}$ \\
\hline TDN dari hijauan (kg/hari) (TDN of forage (kg/day)) & $0,67^{a}$ & $0,31^{b}$ \\
\hline TDN dari konsentrat (kg/hari) (TDN of concentrate ( $\mathrm{kg} /$ day)) & $0,27^{a}$ & $0,29^{b}$ \\
\hline Total TDN (kg/hari) (total of TDN (kg/day)) & $0,94^{\mathrm{a}}$ & $0,60^{b}$ \\
\hline
\end{tabular}

Konsumsi air di dua lokasi penelitian menunjukkan perbedaan nyata $(\mathrm{P}<0,05)$. Perbedaan konsumsi air tersebut dapat disebabkan oleh temperatur yang berbeda. Temperatur yang tinggi di Bantul menyebabkan konsumsi air mencapai 0,7 liter/hari sementara di Kulon Progo dengan temperatur yang rendah, konsumsi air 0,5 liter/hari. Semakin tinggi temperatur lingkungan, semakin tinggi pula konsumsi air untuk digunakan mengganti cairan yang hilang sebagai keringat untuk menyeimbangkan temperatur tubuh. Selain temperatur lingkungan, penyebab konsumsi air yang rendah di lokasi Kulon progo adalah kadar air dalam hijauan yang dikonsumsi.

Kambing di lokasi Kulon Progo mempunyai rerata konsumsi protein kasar, serat kasar, dan TDN berturut-turut sebesar $14,26 \mathrm{~g} / \mathrm{kgBB}^{0,75} ; 14,26 \mathrm{~g} / \mathrm{kgBB}^{0,75}$ dan $0,06 \mathrm{~kg} / \mathrm{kgBB}^{0,75}$ sedangkan di lokasi Bantul berturut-turut $\quad 10,87 \quad \mathrm{~g} / \mathrm{kgBB}^{0,75}$; 19,23 g/kgBB ${ }^{0,75}$ dan 0,05 kg/kgBB ${ }^{0,75}$ (Tabel 6). Hasil analisis statistik data konsumsi protein kasar menunjukkan perbedaan nyata $(P \leq 0,05)$. Protein kasar yang dikonsumsi kambing di Kulon Progo sebesar 77\% berasal dari hijauan, sedangkan di Bantul konsumsi PK 54\% dari hijauan. Hasil penelitian ini menunjukkan bahwa hijauan di dataran tinggi yang terdiri dari daun leguminosa menjadi sumber PK lebih baik dibandingkan hijauan di dataran rendah.

Konsumsi protein kasar tersebut terhitung mencukupi kebutuhan kambing. Devendra dan Burn (1994) menyatakan bahwa ternak yang sedang laktasi kebutuhan protein kasarnya sebesar 12,2 g/kgBB.
Rerata konsumsi serat kasar kambing di Kulon Progo lebih rendah dibandingkan di Bantul $(P \leq 0,05)$ karena kandungan serat kasar dalam hijauan maupun konsentrat yang diberikan di Kulon Progo lebih rendah dari pada di Bantul 18,37\% dan 5,46\% dibanding $25,60 \%$ dan $10,78 \%$. Tingginya konsumsi serat kasar dapat mempengaruhi kadar lemak susu kambing yang dihasilkan.

Wattiaux (1998) menyatakan bahwa rasio pakan yang mengandung lebih banyak hijauan menyebabkan mikrobia rumen akan mengubah karbohidrat menjadi kurang lebih $65 \%$ asam asetat, $20 \%$ asam propionat, dan $15 \%$ asam butirat. Hal ini akan mempengaruhi suplai asetat memadai untuk memaksimalkan produksi lemak.

Rerata konsumsi energi dalam bentuk TDN pada kambing di Kulon Progo adalah 0,94 $\pm 0,10 \mathrm{~kg} /$ hari, sedangkan kambing di Bantul adalah 0,60 $\pm 0,02 \mathrm{~kg} / \mathrm{hari}$. Hasil analisis statistik menunjukkan bahwa konsumsi energi pada kambing di Kulon Progo lebih tinggi dibandingkan di Bantul $(P \leq 0,05)$ karena kandungan TDN pada hijauan maupun konsentrat di Kulon Progo lebih tinggi, yaitu 60,86 dan $72,63 \%$ dibanding 57,50 dan $65,69 \%$. Rerata konsumsi TDN kambing di Kulon Progo mencapai $0,06 \mathrm{~kg} / \mathrm{kgBB}^{0,75}$ sedangkan di Bantul $0,05 \mathrm{~g} / \mathrm{kgBB}^{0,75}$. Nilai tersebut sama dengan $24,46 \mathrm{~g} / \mathrm{kgBB}$ dan $15,78 \mathrm{~g} / \mathrm{kgBB}$. Kebutuhan energi dalam bentuk TDN untuk kambing adalah 18,91 g/kgBB (NRC, 1981). Berdasarkan data tersebut konsumsi energi pada kambing di Kulon Progo terpenuhi, sedangkan di Bantul di bawah standar kebutuhan. 
Hasil penelitian ini menunjukkan bahwa perbedaan jenis pakan yang diberikan mempengaruhi banyaknya nutrien yang dikonsumsi. Pakan hijauan yang sebagian besar terdiri dari rambanan ternyata menjadi sumber nutrien lebih baik untuk memenuhi kebutuhan nutrien pada kambing perah. Siregar (1994) menyatakan bahwa banyak sedikitnya konsumsi TDN dipengaruhi oleh nutrien dalam bahan pakan karena total digestible nutrient merupakan jumlah energi yang dapat dicerna yang berasal dari kandungan nutrien pakan.

\section{Produksi susu kambing}

Rerata produksi susu kambing di Kulon Progo adalah 501,71 g/hari, berdasarkan analisis statistik lebih banyak dibandingkan produksi susu kambing di Bantul, yaitu $419 \mathrm{~g} / \mathrm{hari}(\mathrm{P} \leq 0,05)$. Demikian juga kadar lemak, protein dan total solid susu kambing di Kulon Progo lebih tinggi dibandingkan susu kambing di Bantul. Kambing di Kulon Progo dan Bantul hanya diperah sekali dalam sehari. Hal ini dilakukan untuk efisiensi waktu dan tenaga. Keadaan ini juga mempengaruhi produksi susu yang dihasilkan. Attabany (2002) menyatakan bahwa produksi susu lebih tinggi 5 sampai $20 \%$ pada pemerahan tiga kali sehari daripada dua kali sehari dan pemerahan empat kali lebih tinggi 5 sampai $10 \%$ daripada pemerahan tiga kali sehari.

Produksi susu kambing di lokasi Kulon Progo lebih banyak dibandingkan di Bantul. Rerata temperatur dan kelembaban harian $26,67 \pm 0,80^{\circ} \mathrm{C}$ dan $69,52 \pm 7,40 \%$ lebih nyaman bagi kambing dibandingkan pada lingkungan yang memiliki rerata temperatur dan kelembaban harian $29,10 \pm 0,70^{\circ} \mathrm{C}$ dan $84,29 \pm 5,07 \%$. Hasil penelitian ini me- nunjukkan bahwa temperatur berpengaruh terhadap produksi susu kambing PE. Harding (1990) menyatakan bahwa zona nyaman bagi ternak kambing perah dalam berproduksi secara normal adalah zona yang memiliki temperatur 18 sampai $27^{\circ} \mathrm{C}$. Perbedaan lingkungan khususnya keadaan iklim mikro dapat bervariasi di tiap daerah karena ada perbedaan ketinggian tempat. Keadaan iklim mikro yang tidak sesuai dapat berperan sebagai faktor penghambat terhadap kenormalan proses fisiologi ternak, dan akhirnya akan menekan kemampuan ternak untuk berproduksi secara normal (Wijono et al., 1993).

Temperatur lingkungan dan ketersediaan air yang berbeda di dua lokasi menyebabkan pakan yang dapat tumbuh di dua lokasi berbeda, sehingga pemberian pakan tidak dapat disamakan untuk penelitian yang kemudian berpengaruh terhadap produksi susu kambing PE di dua lokasi. Sodiq dan Abidin (2009) menyatakan bahwa banyak faktor yang mempengaruhi produksi susu, tetapi jenis pakan dan kualitas pakan yang diberikan berpengaruh besar terhadap produksi susu yang dihasilkan.

Hasil penelitian menunjukkan bahwa berat jenis dan kadar protein susu kambing di Kulon Progo lebih tinggi dari Bantul

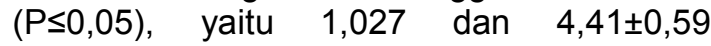
dibandingkan 1,026 dan 3,97\%. Kadar lemak susu kambing di Bantul lebih tinggi, karena pakan yang diberikan di Bantul mengandung serat kasar lebih tinggi dibandingkan pakan kambing di Kulon Progo karena 50\%nya terdiri dari rumput. Kadar lemak dan kadar protein susu kambing dalam penelitian ini lebih tinggi dari susu kambing hasil penelitian Winarno (2002), yaitu 4,22\% dan 3,55\%.

Tabel 7. Rerata produksi dan komposisi susu kambing (the mean of production and composition of goat milk)

\begin{tabular}{|c|c|c|}
\hline & \multicolumn{2}{|c|}{ Lokasi (location) } \\
\hline & Kulon Progo & Bantul \\
\hline Produksi susu (g/ekor/hari) (milk production (g/head/day)) & $501,71 \pm 168,05^{a}$ & $419,71 \pm 197,84^{b}$ \\
\hline Kadar lemak (\%) (fat content (\%)) & $4,84 \pm 1,51^{a}$ & $6,30 \pm 0,81^{b}$ \\
\hline Kadar protein (\%) (protein content (\%)) & $4,41 \pm 0,59^{a}$ & $3,97 \pm 0,68^{b}$ \\
\hline Total bahan padat (total solid) & $13,26 \pm 0,0^{\mathrm{a}}$ & $14,69 \pm 0,02^{b}$ \\
\hline Produksi lemak susu (g) (milk fat production (g)) & $24,28 \pm 8,14^{a}$ & $20,31 \pm 9,57^{b}$ \\
\hline Produksi protein susu (g) (milk protein production $(g)$ ) & $22,12 \pm 7,41^{\mathrm{a}}$ & $16,66 \pm 7,85^{\mathrm{b}}$ \\
\hline
\end{tabular}


Perbedaan kadar lemak susu di dua lokasi dapat terjadi akibat perbedaan jenis pakan yang diberikan pada kambing. Pada penelitian ini konsumsi BK hijauan dan konsentrat pada kambing di Kulon Progo sebesar 76\%:24\% sedangkan di Bantul 58\%:42\% (Tabel 5). Hasil ini sesuai dengan penelitian Mardalena et al. (2008) bahwa lemak susu akan menurun jika diberikan konsentrat, karena kandungan protein yang tinggi dalam konsentrat merupakan pemacu produksi asam propionat di dalam rumen yang kemudian diserap darah. Kandungan lemak tinggi pada susu kambing di Bantul dapat disebabkan oleh proporsi rumput yang tinggi pada pakan hijauan yang diberikan, sehingga konsumsi serat kasar juga tinggi.

Kadar protein susu di dua lokasi tersebut masih berada dalam kisaran normal. Berbagai faktor diketahui mempengaruhi komposisi kimia susu. Temperatur lingkungan dipengaruhi oleh daerah ketinggian, semakin tinggi suatu daerah maka semakin rendah temperatur lingkungannya. Bayong (2004) menyatakan bahwa temperatur yang berbeda dapat menyebabkan perbedaan komposisi kimia susu.

Berat jenis susu kambing di dua lokasi masih berada pada kisaran normal. Attabany (2002) menyatakan bahwa berat jenis susu memiliki kisaran 1,027 sampai 1,035. Berat jenis susu dipengaruhi oleh kandungan total solid, air, dan kadar lemak. Peningkatan nilai berat jenis terutama disebabkan terbebasnya gas-gas seperti $\mathrm{CO}_{2}$ dan $\mathrm{N}_{2}$ yang terdapat dalam susu yang baru saja diperoleh dari proses pemerahan. Siregar (1982) menyatakan bahwa temperatur dapat berpengaruh terhadap berat jenis susu, panas menyebabkan susu berkembang dan jadi lebih ringan, sedangkan susu dingin akan lebih padat dan lebih berat.

\section{Kesimpulan}

Kesimpulan dari penelitian ini adalah kondisi lingkungan menyebabkan perbedaan produksi dan komposisi susu kambing Peranakan Ettawa salah satunya diakibatkan oleh perbedaan komposisi pakan dan konsumsi nutrien, sebagaimana hasil yang diperoleh di Kulon Progo dan Bantul. Kambing PE di dataran tinggi menunjukkan produksi susu dan kadar protein lebih tinggi tetapi kadar lemak susu lebih rendah.

\section{Daftar Pustaka}

AOAC. 1980. Official Method of Analysis, The Association of Official Analytical Chemist, $12^{\text {th }}$ edn. Washington, DC, pp 35.

Atabany, A. 2001. Studi kasus produksi kambing Peranakan Ettawa dan kambing Saanen pada peternakan kambing Barokah dan PT Taurus Dairy Farm. Tesis Program Pasca Sarjana, Institut Pertanian Bogor, Bogor.

Atabany, A. 2002. Program Pendidikan Ketrampilan Hidup. Buku Panduan Pelatihan Usaha Peternakan Kambing di Kelurahan Cipedak Jakarta Selatan. Direktorat Pendidikan Masyarakat, Direktorat Jenderal Pendidikan Luar Sekolah dan Pemuda, Departemen Pendidikan Nasional, Jakarta.

Bayong, T. H. K. 2004. Klimatologi. Institut Teknologi Bandung, Bandung.

Devendra, C. and M. Burns. 1994. Produksi Kambing di Daerah Tropis. Terjemahan. Penerbit ITB, Bandung.

Ganong. 1991. Ternak Potong dan Kerja. Cetakan ke 9. CV. Yasaguna, Jakarta.

Harding, F. 1990. Milk Quality. Aspen Publisher, Inc. Gaithersburg, Maryland.

Hartadi, H., S. Reksohadiprojo, dan A. D. Tillman. 2005. Tabel Komposisi Pakan untuk Indonesia. Cetakan ke-5. Gadjah Mada Press, Yogyakarta.

Hadiwiyoto, S. 1982. Teknik Uji Mutu Susu dan Hasil Olahannya. Liberty, Yogyakarta.

Handoko. 1995. Klimatologi Dasar. Pustaka Jaya, Jakarta.

Leeson, S. 1986. Nutrional consideration of poultry during heat strees. Poult. Sci. 42: 69-81.

Mardalena, Adriani, dan F. Manin. 2008. Peningkatan produksi susu kambing Peranakan Ettawa melalui aplikasi teknologi pemberian konsentrat suplemen blok di Kabupaten Muaro Jambi. Jurnal Pengabdian pada Masyarakat: 24-35.

NRC. 1981. Nutrient Requirementof Goats Angora Dairy and Meat in Temperate and Tropical Countries. National Academy Press, Washington DC.

Parakkasi, A. 1999. IImu Nutrisi dan Makanan Ternak Ruminansia. UI Press, Jakarta. 
Payne, W. J. A. 1970. Cattle Production in the Tropic Longman Group Ltd., London.

Siregar, S. B. 1982. Pengaruh daerah ketinggian terhadap penggunaan makanan, status faali, dan pertumbuhan kambing lokal. Tesis Fakultas Peternakan, Universitas Gadjah Mada, Yogyakarta.

Sodiq, A. dan Z. Abidin. 2009. Meningkatkan Produksi Susu Kambing Peranakan Ettawa. Cetakan Kedua. Agromedia Pustaka, Jakarta.
Wattiaux, M. A. 1998. Nutrition and Feeding. Department of Dairy Science. Babcock Institute. www.babcock.cals.edu. Diakses pada 13 Februari 2013.

Wijono, D. B., Komarudin-Ma'sum, U. Umiyasih, dan A. Rasyid. 1993. Penampilan produksi dan kualitas susu sapi perah turunan Eks-Impor di daerah ketinggian tempat yang berbeda di Jawa Timur. Jurnal IImiah Penelitian Ternak Grati 3: 67-71.

Winarno, F. G. 2002. Kimia Pangan dan Gizi. PT Gramedia Pustaka Utama, Jakarta. 